\title{
Closing the Gap in Building Performance: Learning from other BIM benchmark industries.
}

\author{
Paul G Tuohy*, Gavin B Murphy. \\ Energy Systems Research Unit (ESRU), Mechanical and Aerospace Engineering, \\ University of Strathclyde, Glasgow, G1 1XJ, UK. \\ * Corresponding author: paul.tuohy@strath.ac.uk
}

\begin{abstract}
It is clear that current industry process needs to improve in order to routinely deliver comfortable low carbon buildings. Overheating in buildings designed to be low energy is one of the key symptoms of current problems. Many initiatives aim to improve building performance and the industry process. A selection are reviewed including the EU Energy Performance of Buildings Directive (EPBD); the Green Star, LEED, BREEAM and NABERS rating schemes; the $\mathrm{PH}$ standard; the Soft Landings process and Building Information Modelling (BIM). The BIM approach is being actively promoted based on the assertion that buildings industry process has stagnated compared to other industries suggested as productivity benchmarks such as the electronics industry. This study highlights the potential role that could be played by Building Information Modelling (BIM) as a framework to address the performance gaps, and suggests that processes from the BIM benchmark industries should be investigated for potential adoption. The organisational context and processes of the electronics industry are described and it is proposed that they could be usefully adapted to reduce the scale and impacts of the building industry performance gap. Key conclusions are that public domain performance data is important and that the adoption of a quality systems approach will be required to deliver the intended performance in practice, eliminate overheating and avoid excess energy use.
\end{abstract}




\section{Introduction: A selection of current building industry initiatives}

In the partner paper by the same authors it was highlighted that there are performance gaps that must be addressed in order to avoid overheating and deliver comfortable low carbon buildings (Tuohy and Murphy 2015). Here it is recognised that the buildings industry in the UK and globally is going through a period of rapid change, there are many policy and industry initiatives developed to improve building performance and building industry processes. The relative merits and effectiveness of a range of initiatives, selected to be representative, are reviewed here and general conclusions on their potential impacts drawn from the review. The primary focus of such current policy initiatives is on energy use and carbon emissions but increasingly also indoor environmental performance. The initiatives considered include the UK DEC, Soft Landings, and NABERS processes mentioned in the partner paper.

The range of initiatives considered is summarised in tables 1 and 2, brief descriptions are given below.

In its Energy Performance of Buildings Directive, EPBD1 (EU, 2002), the European Union required energy performance-based building regulations and energy performance certificates (EPCs). At a minimum, the performance calculation must cover energy use for space and water heating, cooling, lighting and ventilation. The recast, EPBD2 (EU, 2010) identified the need for incremental improvements and targets 'nearly zero energy' standards for new and retrofit buildings. Many supporting EU standards have been developed including CEN13790 which describes predictive methods to calculate building energy performance (CEN, 2007) and CEN15251 (CEN 2007b) which describes environmental conditions to be met.

Individual EU member states must enact legislation to meet the EPBD. For UK public and commercial buildings this includes: the CEN13790 compliant National Calculation Method (NCM) and the associated Standard Building Energy Model (SBEM) (BRE 2014). The energy prediction covers the minimum set of end-uses defined in the EPBD, which the industry has come to call "regulated loads". This predictive method is used in somewhat different ways for regulatory approval and to produce the "Asset Rating" predicted performance for EPCs.

The EPBD also requires that in public buildings over $1000 \mathrm{~m}^{2}$ energy certificates are displayed. Many countries (including Scotland) display predicted EPCs, but in England, Wales and Northern Ireland it was successfully argued that in order to motivate better management, a Display Energy Certificate (DEC) (CIBSE 2009) should be based on actual energy use in operation and renewed annually. This "Operational Rating" uses a different, semi-empirical benchmarking procedure, (CIBSE 2008), which takes account of all energy end-uses.

Passivhaus (PH) is an energy performance standard being promoted across the EU and worldwide (PHI, 2012). While concentrating on minimising energy requirements for heating, cooling and ventilation, the standard includes predicted energy for all uses within its criteria. To address quality issues the Passivhaus Institut has developed its own CEN-compliant 
PHPP predictive software (PHI, 2012) which includes a simplified overheating calculation, and provides training and accreditation of $\mathrm{PH}$ Designers and independent Certifiers.

While the EPBD largely concentrates on predicted energy in use, other aspects of sustainability such as transport, health, embodied energy and carbon, and ecology are recognised in voluntary standards and rating systems such as the Building Research Establishment's Environmental Assessment Method BREEAM (BRE, 2012), 'The Code for Sustainable Homes' (DCLG, 2010), and 'Scottish Technical Standards Section 7: Sustainability' (Scot Gov, 2011).

EU and UK initiatives are mirrored in other countries, states and regions, with the LEED (USGBC, 2012) sustainability standard in the USA having similarities to BREEAM. The California Title 24 standards (CEC, 2012) dictate aggressive energy performance to be achieved by new and modified domestic and non-domestic buildings. These US standards are based on approved predictive energy performance calculation methods. The US also has the voluntary Energy Star (2012) Portfolio Manager building rating scheme based on actual energy use compared with benchmarks for various building types.

The Australian Green Star rating scheme has historically been a sustainability rating scheme similar to BREEAM and LEED with its energy component based on predictive methods. Recently it has announced an operational sustainability rating 'Green Star Performance' (GBCA 2011), for which the energy performance rating will be harmonised with the longstanding ABGR, the Australian Buildings Greenhouse Rating, which now forms part of the National Australian Building Environmental Rating Standards NABERS (2012) scheme.

ABGR was first launched for large office buildings in New South Wales in 2000 and is based on operational energy use normalised by building type and use pattern. It is now a national system and is being gradually extended to other building types, and declaration has recently become mandatory for landlord's services in office buildings over $2000 \mathrm{~m}^{2}$. The NABERS scheme also includes water, waste and indoor environment ratings. NABERS energy ratings are based only on operational energy data but NABERS can be used in pre-operation marketing where a "Commitment Agreement" is signed and a protocol followed that includes design review by experts, a rigorous specification for the appropriate use of simulation, and the inclusion of fault tolerance and risk analysis in the design process. There are no ratings given on the basis of design predictions, NABERS ratings are only given based on actual energy performance once in operation.

In the UK, USA and Australia there have been initiatives to improve the design, construction, commissioning and handover processes to achieve better performance in practice. In BREEAM and LEED there are increasing credits for seasonal commissioning and submetering.

In the UK the Soft Landings process has been developed and launched to encourage a collaborative approach to the design process, a focus on outcomes, inclusion of expert reviews, a smooth handover to the building user, a 3 year period of handover, performance optimisation or remediation and post occupancy evaluation of both occupant perceptions and energy performance (Way and Bordass, 2005, BSRIA, 2012). Soft Landings is being 
integrated in synergy with both BREEAM and the RIBA Plan of Work (2011) and is likely to be adopted in an adapted form for projects by central government.

In parallel with the drive to achieve low carbon, low energy sustainability, the Building Information Modelling and management (BIM) initiative (Succar 2009) aims to provide an integrated building industry process that facilitates interchange of information between partners in the design, construction and operation. BIM has been endorsed by several Governments and Government agencies and is seen as key to improving productivity and competitiveness perceived to have stagnated in the buildings industry compared to other industrial sectors including retail, aerospace, automotive and electronics (BSI, 2012). The aim of BIM is to have a common data model for use in the building design and operation by all participants. The UK's BIM roadmap goes from the current mix of paper and electronic 2D and 3D datasets and models through a common 3D model, to modelling that incorporates time, cost and facilities management dimensions (4D, 5D and 6D models respectively). It is also being integrated with the RIBA (RIBA 2012) plan of work. The UK BIM Taskforce has recently announced the intention to support 'Government Soft Landings (GSL)' for the Government estate as a BIM priority after successful trials (GSL 2012).

It has been proposed that key elements in the productivity and performance improvements in BIM benchmark industries have been the customer and media focus on actual product performance and the adoption of a lean quality systems approach to design and build processes (Tuohy, 2009a).

There are then many industry initiatives aimed at improved buildings and building industry performance, the extent to which these initiatives will address the observed performance disconnects remains to be seen. The identification of industries with improved process by BIM proponents suggests a comparison with these industries may be a useful exercise.

It should be noted that in the above building performance or rating systems the issue of discomfort or over-heating is not a primary focus, even though it is a 'canary' symptom that the systems are not proving 'fit for purpose' in providing a building in which basic comfort can be achieved by the building occupants. At a time when even in high latitudes in countries like Estonia overheating of ordinary homes is becoming commonplace (Maivel et al., 2015) then the success of design strategies and buildings in use should perhaps be measured not only by energy use and carbon emissions but by a critical performance variables such as hours and extent of over-heating within the occupied building using criteria such as those suggested by the CIBSE Overheating Task Force (CIBSE 2013). 
Table 1. A selection of EU and UK Policy and Industry Initiatives.

\begin{tabular}{|c|c|}
\hline \multicolumn{2}{|l|}{ EU Legislation } \\
\hline $\begin{array}{l}2002 \text { Energy } \\
\text { Performance of } \\
\text { Buildings Directive. }\end{array}$ & $\begin{array}{ll}\text { o } & \text { Energy Performance Certificates (EPCs) at sale / rental. } \\
\text { o } & \text { Building regulations updates to improve energy } \\
\text { performance for New Buildings. }\end{array}$ \\
\hline $\begin{array}{l}2010 \text { Energy } \\
\text { Performance of } \\
\text { Buildings Directive. }\end{array}$ & $\begin{array}{ll}\text { o } & \text { Nearly Zero Energy Standards for New and Retrofit. } \\
\text { o } & \text { Minimum standards for existing buildings at sale / rental. }\end{array}$ \\
\hline \multicolumn{2}{|c|}{ EU EPBD Implementation - Individual Country Legislation - UK } \\
\hline $\begin{array}{l}\text { Building } \\
\text { regulations } \\
\text { (England, Wales } \\
\text { and Northern } \\
\text { Ireland) }\end{array}$ & $\begin{array}{ll}\text { O } & \begin{array}{l}\text { Regulation compliance based on predicted } \\
\text { performance. }\end{array} \\
& \text { EPCs based on predicted performance except for public } \\
& \text { buildings }>1000 \mathrm{~m}^{2} . \\
0 & \text { EPCs (Display Energy Certificates (DECs)) based on } \\
& \text { actual energy use for public buildings }>1000 \mathrm{~m}^{2} . \\
\end{array}$ \\
\hline \multicolumn{2}{|c|}{ EU Supported Building Energy Performance Standard } \\
\hline Passivhaus & $\begin{array}{ll}\text { o } & \text { Advanced energy performance standard promoted } \\
\text { through EU dissemination projects. } \\
\text { o Compliance based on predicted performance plus } \\
\text { blower door air tightness test. }\end{array}$ \\
\hline \multicolumn{2}{|c|}{ UK Government supported voluntary sustainability rating systems } \\
\hline BREEAM & $\begin{array}{ll}\text { o } & \text { Sustainability rating system for non domestic buildings } \\
\text { (and domestic refurbishment). } \\
\text { o } & \text { Requirement for UK Government projects. } \\
0 & \text { Ratings based on predicted performance. } \\
0 & \text { Commissioning and sub-metering encouraged. } \\
0 & \text { Monitored performance fed back to improve process. }\end{array}$ \\
\hline $\begin{array}{l}\text { Scottish building } \\
\text { regs. Sect } 7 \text {. }\end{array}$ & $\begin{array}{ll}\text { o } & \begin{array}{l}\text { Sustainability rating system for domestic and non } \\
\text { domestic (Voluntary). }\end{array} \\
\text { o } & \text { Ratings based on predicted performance. }\end{array}$ \\
\hline $\begin{array}{l}\text { Code for } \\
\text { Sustainable } \\
\text { Homes }\end{array}$ & $\begin{array}{ll}\text { o } & \text { Sustainability rating system - domestic (like BREEAM). } \\
\text { o } & \text { Ratings based on predicted performance. }\end{array}$ \\
\hline \multicolumn{2}{|c|}{ UK Buildings industry process frameworks } \\
\hline $\begin{array}{l}\text { Royal Incorp. of } \\
\text { British Architects } \\
\text { (RIBA) Plan of } \\
\text { Work. } \\
\text { Construction } \\
\text { Industry Council } \\
\text { (CIC) Work } \\
\text { Stages. }\end{array}$ & $\begin{array}{ll}\text { o } & \text { RIBA framework for construction process from } \\
\text { Architecture perspective; established over } 50 \text { years. } \\
\text { o Recently added Green and BIM Overlays to RIBA Plan } \\
\text { of Work to synergise with Soft Landings and BIM } \\
\text { initiatives (see below). } \\
\text { o New revision of RIBA Plan of Work due in 2013, to be } \\
\text { aligned with the CIC Work Stages. }\end{array}$ \\
\hline \multicolumn{2}{|c|}{ UK Government supported buildings industry process initiatives } \\
\hline Soft Landings & $\begin{array}{ll}\text { o } & \text { Framework and Core Principles for design, handover } \\
\text { and post occupancy to ensure optimal performance. } \\
\text { o Participative process in design with expert reviews and } \\
\text { the engagement of team through } 3 \text { year handover. }\end{array}$ \\
\hline
\end{tabular}




\begin{tabular}{|c|c|c|}
\hline & & $\begin{array}{l}\text { Adopted for Government Projects after positive pilots } \\
\text { (Government Soft Landings (GSL)). }\end{array}$ \\
\hline $\begin{array}{l}\text { Building } \\
\text { Information } \\
\text { Modelling (BIM) }\end{array}$ & $\begin{array}{l}0 \\
0\end{array}$ & $\begin{array}{l}\text { Initiative aimed at improving buildings industry process } \\
\text { through use of digital information. } \\
\text { UK BIM policy and BIM Task Force established. } \\
\text { Construction Operations Building Industry Information } \\
\text { Exchange (COBie) standard schema adopted. } \\
\text { Development in partnership with industry organisations } \\
\text { including the UK Construction Industry Council (CIC), } \\
\text { RIBA and CIBSE. } \\
\text { BIM support for existing legislative and voluntary } \\
\text { performance standards based on predicted } \\
\text { performance. } \\
\text { BIM support for Government Soft Landings (GSL). }\end{array}$ \\
\hline \multicolumn{3}{|c|}{ UK buildings actual performance benchmarking } \\
\hline CarbonBuzz & 0 & $\begin{array}{l}\text { Voluntary database for anonymous building } \\
\text { performance benchmarking. }\end{array}$ \\
\hline $\begin{array}{l}\text { Usable Buildings } \\
\text { Trust }\end{array}$ & & $\begin{array}{l}\text { Performance data for case study buildings. } \\
\text { Methodologies and guidance for post occupancy } \\
\text { evaluations. }\end{array}$ \\
\hline UK DEC database & 0 & $\begin{array}{l}\text { Actual performance data for public buildings }>1000 \mathrm{~m}^{2} \\
\text { available on open database. }\end{array}$ \\
\hline
\end{tabular}


Table 2. A selection of Non EU and UK Initiatives.

\begin{tabular}{|c|c|c|}
\hline \multicolumn{3}{|c|}{ Non EU/UK; Voluntary sustainability and energy rating systems } \\
\hline $\begin{array}{l}\text { LEED (USA) } \\
\text { GreenStar (Aus) }\end{array}$ & $\begin{array}{l}0 \\
0 \\
0 \\
0\end{array}$ & $\begin{array}{l}\text { Sustainability rating systems for non domestic buildings. } \\
\text { Ratings based on predicted performance. } \\
\text { Commissioning and sub-metering encouraged. } \\
\text { Monitored performance fed back to improve process. }\end{array}$ \\
\hline $\begin{array}{l}\text { NABERS } \\
\text { (Australia) }\end{array}$ & & $\begin{array}{l}\text { Energy and indoor environment rating system for non } \\
\text { domestic buildings based on post occupancy evaluation. } \\
\text { Ratings based on actual measured performance. } \\
\text { NABERS can be used in pre-completion marketing only } \\
\text { where a Commitment Agreement is signed. } \\
\text { Commitment agreement includes expert reviews and } \\
\text { specifications for the use of simulations in design and } \\
\text { communications of limitations and risks across design } \\
\text { team including clients. } \\
\text { On completion of a NABERS project the NABERS rating } \\
\text { is given based on actual annual energy use. }\end{array}$ \\
\hline \multicolumn{3}{|c|}{ Non EU/UK; Buildings actual performance and benchmarking } \\
\hline $\begin{array}{l}\text { EnergyStar } \\
\text { GreenStar } \\
\text { (Performance) }\end{array}$ & & $\begin{array}{l}\text { EnergyStar Building performance benchmarking and } \\
\text { awards based on comparative energy use. } \\
\text { GreenStar to be launched } 2013 \text {. }\end{array}$ \\
\hline NABERS & & $\begin{array}{l}\text { Performance data for case study buildings. } \\
\text { Methodologies and guidance for post occupancy } \\
\text { evaluations. }\end{array}$ \\
\hline
\end{tabular}




\section{Comparison with BIM benchmark industries process.}

The BIM initiative in the UK was promoted on the basis of its successful adoption in other industries (BSI 2012). Comparison below of the performance drivers and processes in a BIM benchmark industry, the electronic systems industry, allows assessment of the extent to which these are relevant to the performance gaps in the building industry. Many of the BIM industries have developed processes which enable them to create products that work 'straight out of the box' meeting specified performance, most of the time. The evolution of the BIM benchmark industries is driven by a plethora of publically available performance data. Esteem awards in these industries are to a large extent based on this public domain performance data, and every issue of Which magazine that informs the public on 'best buys' is fed by such data. Manufacturers who have performance issues find it very difficult to be successful. In these industries it is also very important to bring new technologies to market quickly without compromising performance.

While the industrial engineering approaches of these industries have historically been developed to manufacture a 'one-size-fits-all' product, the creation of a customer specific product from a library of available modules has evolved over recent decades and is increasingly common, modular designs are configured and translated to match with available manufacturing processes or meet different performance requirements etc. It is this modular approach which is explored here as a parallel for the buildings industry process. This 'custom' modular industrial engineering approach is arguably already evident in the some specialist areas of the buildings industry such as off-site modular construction, large apartment blocks, hotels, large cruise ships, and the air conditioning industry, where combinations of standardized modules are used.

\subsection{Custom electronic systems process.}

The custom electronic systems industry has been subject to rapidly evolving expectations of performance including functionality, quality, cost, energy use, and robustness. The industry has been the focus of global competition and its end products have been the subject of extreme public scrutiny. Even where there appears to have been 'standard' mass produced products these are subject to rapid modifications to meet evolving market demands and are repeatedly transported to different production technologies to enhance performance, reduce costs, meet new environmental standards etc. Investments required in product development and new technologies are extremely large and market opportunities are very narrowly time bounded with first to market with the required performance achieving huge returns and correspondingly huge financial penalties for any delayed market entry due to performance or other issues. These technical and economic characteristics of this market create a 'survival of the fittest' environment where only those organizations that evolve robust design and build processes have been able to succeed and many large organizations have failed. The processes developed by these industries have evolved to meet the necessary requirements (Pyzdek 2003). Some elements of these processes most relevant to the building industry performance gaps are summarized here: 
- Concept design decisions are largely based on feedbacks of actual performance of whole systems or modules (energy, user feedbacks, costs) including potential risks to be managed, known issues and any limitations.

- The detailed design process includes re-use of modules previously validated and with known performance data. Performance is assessed across the range of environmental and user behaviours to be expected in future use. Risks, issues, and limitations are documented. There is a requirement for quantified and high simulation test coverage including systems and controls. Operational and validation test codes are generated in detailed design stages. Issues are captured as they arise and process improved so they cannot re-occur in future. The FMEA and control mapping approach highlighted earlier in this paper is an example of a process that allows risks, and measures to manage these risks, to be captured and comprehended.

- In the implementation stage a lean quality culture is established throughout the manufacturing process and supply chain including risk and issue management processes to capture and eliminate the possibility of re-occurrence of any issues on future projects.

- The validation process specification is defined at the detailed design stage. The validation process includes quantified test coverage of systems and controls, covering appropriate range of patterns of use, and checks for known risks and fault conditions. Where issues are found they are addressed on the current project and feedback given formally to the appropriate process stage(s) to prevent re-occurrence on future projects.

- On handover to the customer the expectation is that the product will work first time and meet performance specifications. The expectation is that the performance will be visible through simple intuitive displays and when there is a fault the system will identify this and indicate the problem clearly. The expectation is that the operation and controls will be simple and intuitive.

- There is an expectation that actual performance data will be made widely available through the public media.

In summary, the key element driving the electronics industry is the demand for performance and the availability and scrutiny of actual performance data. The response of the electronics industry has been to evolve a lean quality systems approach to meet these demands and maximize the probability that products work first time. So far BIM has focused on the logistics and financial aspects of these industries processes rather than on the approach to quality (Tuohy 2009a, 2013). 


\section{Building industry initiatives compared with BIM benchmark industry process.}

The importance of public scrutiny and reporting of actual performance in the BIM benchmark industries justifies this being added to the design process model (Figure 1).

Figure 1. Simple model of a design flow - with public performance reporting added.

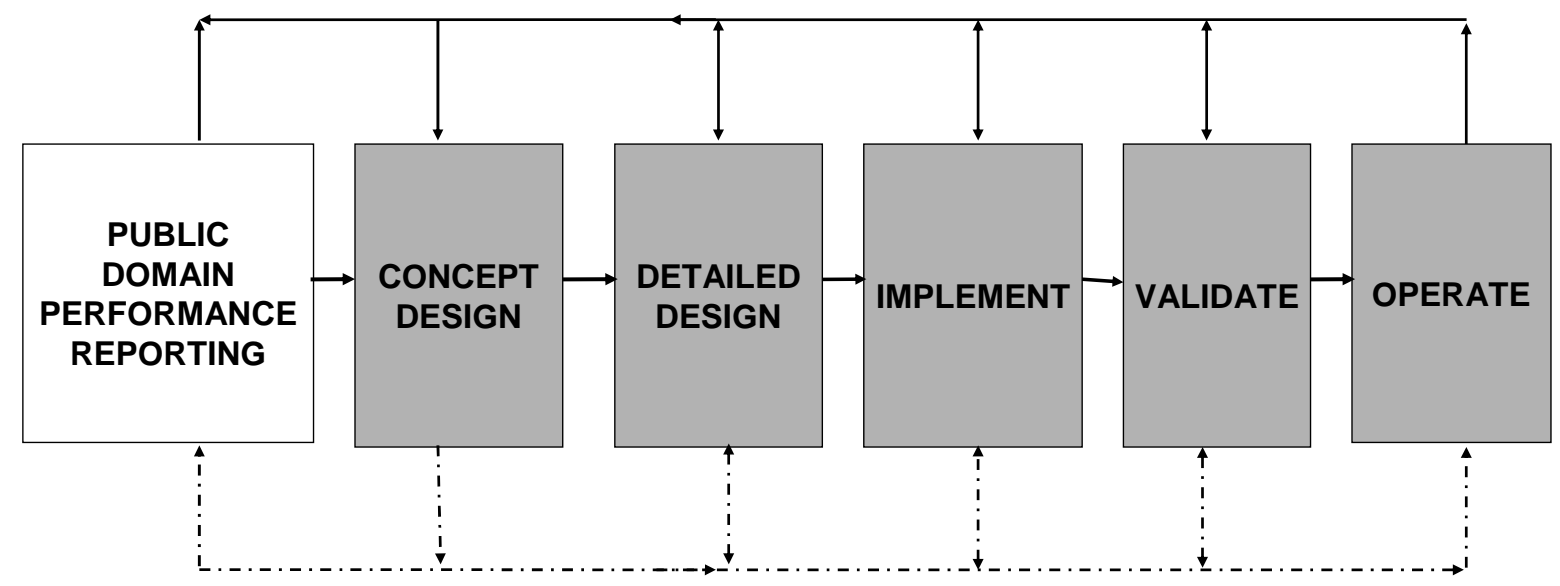

To explore the extent the BIM benchmark industry quality process is being mirrored by current buildings industry initiatives, a selection of these were mapped using this revised model as the template. An overview of this mapping is given in table 3 and summarized in table 4 , the shading of cells in table 3 is dark where the elements of the electronics process exist in the buildings industry process to a significant extent, is light where there is some correspondence but significant elements are missing, unshaded cells indicate that this element has no corresponding element in that buildings industry process. These assessments are discussed further below.

Regarding the reporting of actual performance data, the UK DEC stands out as a mandatory scheme which reports actual energy performance. There has been no move to expand reporting to include environmental performance.

Within the voluntary NABERS scheme there is mandatory public reporting of energy rating based on actual use, and voluntary reporting of indoor environmental performance. Worldwide there are a growing number of voluntary schemes for capturing actual operational energy performance these include Energy Star and 'Green Star Performance'. While these initiatives appear to be steps in the right direction they fall short of the full public scrutiny of actual performance data that has been a driver in electronic systems.

Regarding a quality systems approach throughout the design process, the Soft Landings process core principles and framework can be viewed as a step in this direction. However it currently relies on individual expert or design team inputs and not formal processes such as FMEA. The 3 year post occupancy handover period of analyzing, tuning and optimizing building performance (energy and user experience) serves to highlight causes of 
performance gaps, and may act as an incentive for the design process to be improved to avoid issues in this phase but transfer of knowledge from project to project depends on the individual expert consultants.

The NABERS Commitment Agreement and its associated procedures can also be viewed as having some similarities with a quality system approach, it mandates reviews at critical stages, a specification for the use of simulation, and communication of assumptions and risks to clients and the project team. The commitment agreement has been informed by previous post occupancy evaluations and particularly focuses on the representation of systems and controls which is recognized to be an area of general weakness. The NABERS rating is based on the actual energy performance. The NABERS process gives direct comparison between predicted and actual performance where the Commitment Agreement has been used, and again will act as an incentive to further improve the design process to avoid post-delivery problems.

In Passive House, the Certified Designer accreditation training and independent Certification processes for Designers, Components and Buildings are intended to address quality issues. However, evidence presented in the partner paper (Tuohy 2015) indicates that despite these processes, performance gaps still remain and re-enforces the suggestion that actual performance must be validated.

The UK building regulations (for both compliance and energy ratings), the Passive House standard, LEED, BREEAM and Green Star ratings are (with the notable exception of the UK DEC described above), based on predicted rather than actual performance.

LEED and BREEAM do require reporting of predicted $v$ actual energy performance to their oversight bodies for the generation of anonymised reports, and credits are gained in BREEAM, LEED and Green Star for specifying sub-metering and engaging a commissioning engineer in the earlier concept and detailed design process steps but the route to process improvement here is less direct than for Soft Landings and NABERS.

With regards to delivery of buildings that work 'out of the box' it would appear to need a paradigm shift in the industry for this to happen. Actual performance reporting and the adoption of Soft Landings or NABERS process will provide feedback to improve processes and also a large financial and productivity incentive for companies to get the building to work 'out of the box' and avoid the potential adverse publicity, difficulties and resources involved in post occupancy remediation, providing an incentive for a 'works first time' aspiration to be brought closer to a reality, initially through better design of validation testing and procedures (commissioning) but it remains some way off. 
Table 3. Comparison: Buildings initiatives v. BIM benchmark.

\begin{tabular}{|c|c|c|c|c|c|c|}
\hline 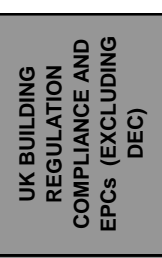 & 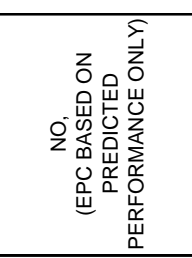 & 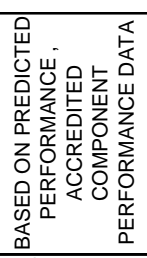 & 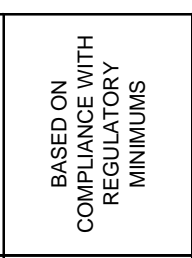 & 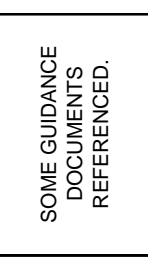 & 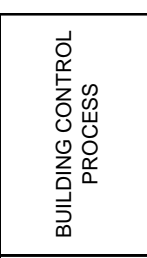 & 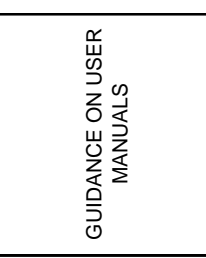 \\
\hline 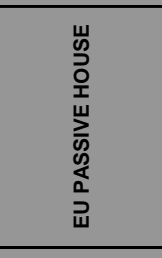 & 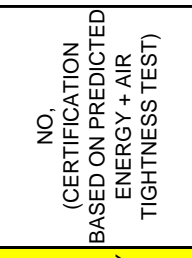 & 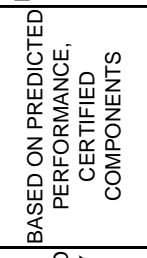 & 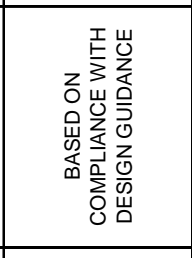 & 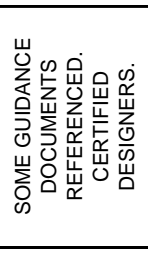 & 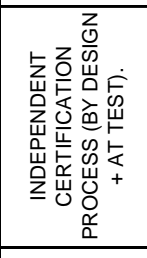 & 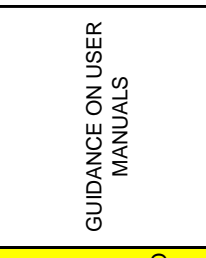 \\
\hline 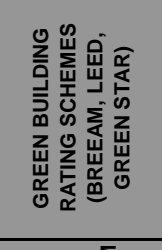 & 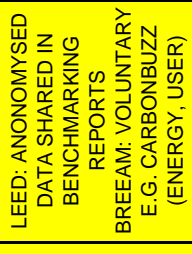 & 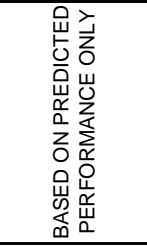 & 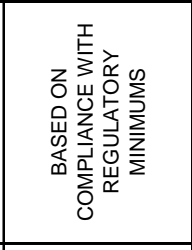 & 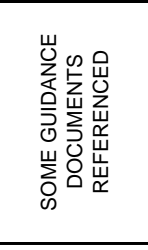 & 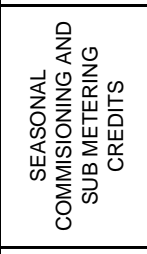 & 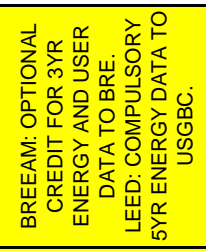 \\
\hline 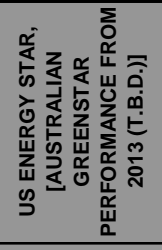 & 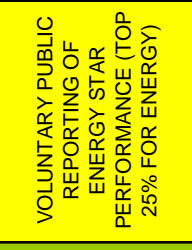 & & & & & 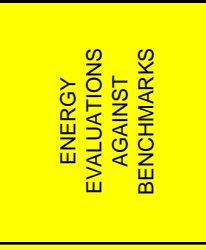 \\
\hline 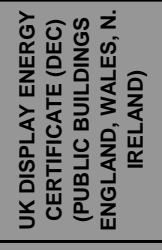 & 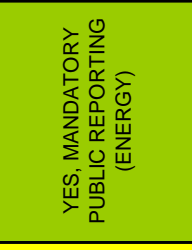 & & & & & 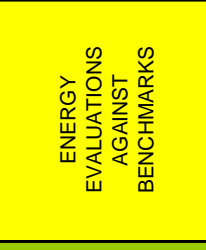 \\
\hline 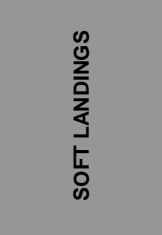 & 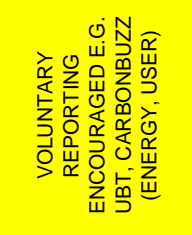 & 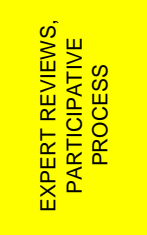 & 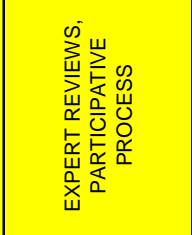 & 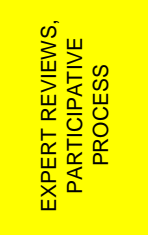 & 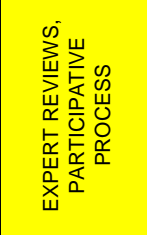 & 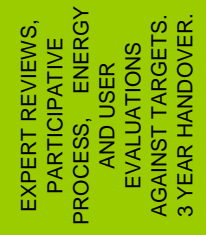 \\
\hline 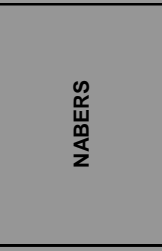 & 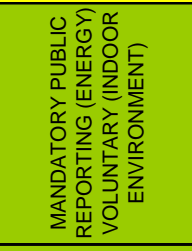 & 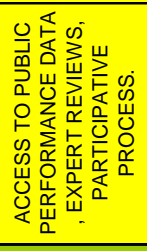 & 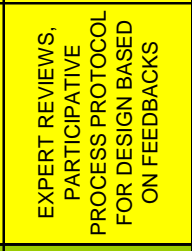 & 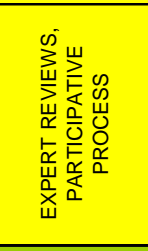 & 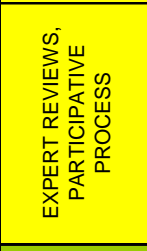 & 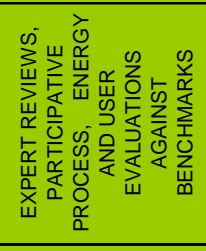 \\
\hline \multirow[t]{2}{*}{ 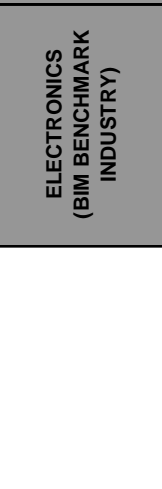 } & 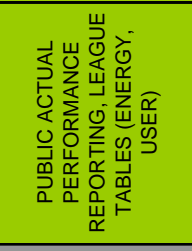 & 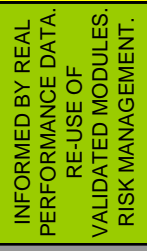 & 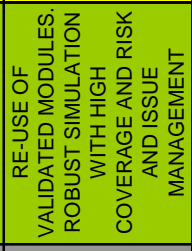 & 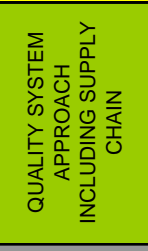 & 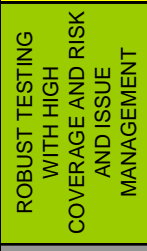 & 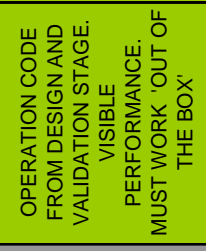 \\
\hline & 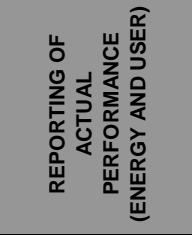 & 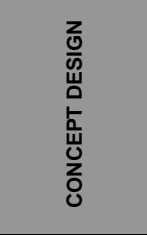 & 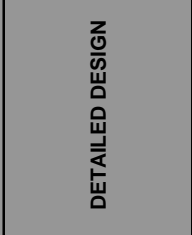 & 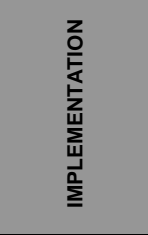 & 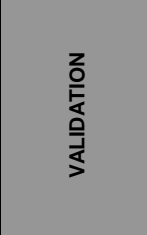 & $\begin{array}{l}\text { zo } \\
\text { o } \\
\text { w } \\
\text { ü }\end{array}$ \\
\hline
\end{tabular}


Table 4. Summary: Buildings initiatives v. BIM benchmark.

\begin{tabular}{|c|c|c|c|}
\hline & $\begin{array}{l}\text { REPORTING OF ACTUAL } \\
\text { PERFORMANCE }\end{array}$ & $\begin{array}{c}\text { QUALITY SYSTEMS } \\
\text { APPROACH TO DESIGN AND } \\
\text { BUILD }\end{array}$ & WORKS FIRST TIME \\
\hline ELECTRONICS & YES & YES & YES \\
\hline DISPLAY ENERGY CERTIFICATE (DEC) & YES & & \\
\hline NABERS & YES & $\begin{array}{l}\text { COMMITMENT AGREEMENT } \\
\text { AND PROTOCOL }\end{array}$ & $\begin{array}{l}\text { PROTOCOL AND NABERS } \\
\text { ACTUAL PERFORMANCE } \\
\text { RATING PROVIDES INCENTIVE }\end{array}$ \\
\hline SOFT LANDINGS & INTERNAL TO TEAM & $\begin{array}{l}\text { CORE PRINCIPLES AND } \\
\text { FRAMEWORK }\end{array}$ & $\begin{array}{l}3 \text { YEAR HANDOVER PROCESS } \\
\text { PROVIDES INCENTIVE }\end{array}$ \\
\hline ENERGY STAR, GREEN STAR Performance. & $\begin{array}{l}\text { PERFORMANCE BASED } \\
\text { AWARDS }\end{array}$ & & \\
\hline EU PASSIVE HOUSE & & CERTIFIERS & \\
\hline $\begin{array}{l}\text { GREEN BUILDING RATING SCHEMES e.g. } \\
\text { BREEAM, LEED, GREEN STAR. }\end{array}$ & $\begin{array}{l}\text { INTERNAL TO RATING } \\
\text { ORGANISATION. } \\
\text { METERING. }\end{array}$ & & SEASONAL COMMISSIONING \\
\hline UK BUILDING REGULATIONS & METERING & & COMMISSIONING \\
\hline
\end{tabular}




\section{Discussion.}

Since Government policy aimed at comfortable low energy buildings is largely enacted through predicted performance for regulated uses rather than actual building performance, it is to be expected then that industry then will become adept at delivering good predicted performance for regulated uses rather than good actual performance.

If the focus was to be on actual rather than predicted performance then this would necessarily lead to industry developing the processes needed to achieve good performance in practice. Economic benefits would then be available from: reduced energy use, productivity improvements associated with improved health and avoidance of key comfort failure metrics captured in over-heating benchmarks, productivity improvements associated with avoiding spending effort on remediation, and increased competitiveness in global markets.

The European Standard EN15251 (CEN 2007b) was developed as part of the backup to the EPBD. It specifies acceptable indoor environments over a number of dimensions ventilation, lighting and noise as well as thermal. It was intended to ensure that energy performance specified by the EPBD is achieved without sacrificing the needs of building occupants and should be a key component in any future definition of good performance in design and in practice.

The principle behind the EU EPBD energy labelling scheme was that labelling would reflect actual performance and create a market that drives industry to deliver good actual performance, the adoption of labelling based on predicted regulated energy use misses out large sections of the industry required to deliver the intended results. Resulting performance gaps may undermine the credibility of labelling schemes.

It would then appear to be essential that actual performance becomes the target. There are practical difficulties with this but the DEC and NABERS processes provide examples of how this can be implemented. Performance ranking and accountability mechanisms based on actual performance such as those that exist for products of other industries should be encouraged e.g. government supplier rankings, consumer organisations ratings etc. Esteem awards and recognition of best practice should only be based on actual verified performance.

There are a number of programs that gather post occupancy performance data on a sample basis and use this data to inform process improvements, examples include EST and TSB evaluations, BREEAM and LEED reporting back of performance data. While these studies will undoubtedly lead to improvements over time there is little evidence (given the large number of historical post occupancy performance studies) that the rate of improvement will be greater than the industry historical trend. More direct accountability plus the motivation provided by potential consequences of public reporting or contractual obligations (e.g. as in Soft Landings or NABERS) would be expected to disrupt this situation and drive the industry more directly to close the gaps. 
The extent to which industrial engineering approaches such as those highlighted in custom electronics will be adopted, and timeframes for these changes if they were to occur, is uncertain. The BIM initiative has highlighted other industries as having consistently higher rates of productivity improvement; there would appear to be an opportunity for a strand within BIM research and the BIM initiative to target development of robust modular design approaches leveraging techniques from these benchmark industries aimed at comfortable, non-overheating, low energy and low carbon performance in practice. It would seem reasonable that BIM should focus more on processes that target actual building performance. The recently stated UK Government BIM Task Force policy to incorporate support for the Government Soft Landings (GSL 2012) process within in the UK BIM initiative is possibly a step in this direction.

Processes that have potential for adoption in the buildings sector include a more formal quality culture embedded across the workforce and supply chain. In electronics everyone involved in the delivery of products is trained in quality.

Soft Landings and NABERS have commitments, frameworks, core principles and guidance which support transfer of knowledge and process improvements. These rely largely on inputs from individual experts in contrast to the more prescriptive and automated approaches of the custom electronics industry which require knowledge to be captured in standard modular formats using FMEAs control maps or similar.

It is probable that a more automated and formal modular and quality systems based approach to design, if it is to evolve, will evolve first driven internal to large organisations, such as Government, which procure large numbers of buildings (the US military has already played a leading role in the BIM initiative), or within larger companies delivering high volumes of buildings (some large companies already have both buildings and industrial engineering skillsets). This modular approach could be supported by customisable design software within the BIM framework. There is however also the opportunity for smaller organisations to establish this modular approach as a vehicle for improved effectiveness.

A recurring problem area appears to be the design, implementation and validation of controls, particularly with respect to new technology systems, the NABERS and Soft Landings processes make efforts in this area while recognising limitations in current design and modelling tools. These limitations in design and modelling tools remain to be addressed, methods for better incorporating control into detailed design and validation is the focus of ongoing research.

Indoor environmental performance and user perceptions of buildings have not been addressed to the same extent as energy and carbon in industry initiatives and indeed this paper reflects that, but this must be similarly addressed (e.g. performance measurement criteria exist within Soft Landings, NABERS etc), many of the overheating and environmental performance problems are readily observable symptoms of the issues, and if resolved, will positively impact on energy, carbon as well as indoor environment and consequently health wellbeing and productivity. 


\section{Conclusions}

Current policy initiatives aimed at delivery of comfortable, low carbon buildings are largely based on predicted performance. There are significant disconnects between predicted and actual building comfort and energy performance so that current policy intent is unlikely to be met.

A comparison with the process of the custom electronics industry, suggested as a BIM benchmark, was used to suggest measures with potential to address these disconnects, these include:

- Establishing accountability for actual building performance.

- Esteem awards and high ratings of buildings only to be awarded based on actual performance.

- Adoption of a modular robust design and implementation process including feedbacks and feed-forwards within a quality systems approach.

- FMEA and control mapping to be used across the design process and to transfer knowledge from project to project.

DECs, Soft Landings and NABERS are highlighted as the buildings industry initiatives most likely to deliver intended building performance in practice but gaps remain. It is suggested that if actual performance measurement is targeted then the buildings industry will develop the processes required to deliver good actual performance while maximizing productivity. The BIM initiative is largely focused on more efficiently supporting current industry processes which are based on predictive methods. It is suggested that BIM should be re-focused on achieving actual building performance. It is also suggested that processes from BIM benchmark industries merit further investigation.

This highlights a further non-technical barrier to the improvement of buildings, in that a key route to enabling the building design professions and the construction and development industries to overcome their reluctance to make public the actual performance metrics of the buildings they produce, is by making the public publication of such data mandatory, as it is in the motor and electronics industry. This requires political leadership to move on building markets, as well as sensible ways of making increasingly complex buildings perform better. 


\section{Acknowledgement}

The investigations carried out on the case study buildings were possible due to support from the Building Research Establishment, Fyne Homes, Gokay Deveci Architect, Renewable Heat Strategies, MEARU.

\section{References}

BRE (2014) National Calculation Method. www.ncm.bre.co.uk

BRE (2014a) BREEAM. www.breeam.org

BSI (2012), 'Investors Report: Building Information Modelling (BIM)'

http://www.bsigroup.com/upload/Standards\%20\&\%20Publications/Building/InvestorsReportBIM.pdf

BSRIA (2012) Soft Landings. http://www.bsria.co.uk/services/design/soft-landings/

California Energy Commission (CEC) (2012) Building Energy Efficiency Program http://www.energy.ca.gov/title24/

CEN (2007). Energy Performance of Buildings - Calculation of Energy Use for Space Heating and Cooling, ISO Standard 13790, Geneva.

CEN (2007b) CEN Standard EN 15251: Indoor Environmental Input Parameters for Design and Assessment of Energy Performance of Buildings Addressing Indoor Air Quality, Thermal Environment, Lighting and Acoustics, Comite' Europe'en de Normalisation, Brussels.

CIBSE (2008), Technical Memorandum TM46, Energy Benchmarks, Chartered Institute of Building Services Engineers, London.

CIBSE (2009), Technical Memorandum TM49, Operational Ratings and Display Energy Certificates, Chartered Institute of Building Services Engineers, London.

CIBSE (2013) Technical Memorandum, No 52 The limits of thermal comfort: avoiding overheating in European buildings, CIBSE London Chartered Institution of Building Services Engineers

DCLG (2008) Code for Sustainable Homes: Setting the standard in sustainability for new homes. Product Code 07BD05109.

http://www.planningportal.gov.uk/buildingregulations/greenerbuildings/sustainablehomes/

Energy Star (2012) Energy Star for Buildings and Plants.

http://www.energystar.gov/index.cfm?c=business.bus_index

EU (2002). 'On the Energy Performance of Buildings', Directive 2002/91/EC of the European Parliament.

EU (2010). 'On the Energy Performance of Buildings (recast)', Directive 2010/31/EU of the European Parliament. 
GBCA (2011) Green Star Performance Scoping paper Stakeholder Feedback Report DATE http://www.gbca.org.au/uploads/146/3474/GSP_FEEDBACK_REPORT_FINAL_DEC_2011. pdf

Government Soft Landings (GSL) (2012) http://www.bimtaskgroup.org/wpcontent/uploads/2012/09/The-Government-Soft-Landings-Policy.doc

Maivel, M., J. Kurnitski and T. Kalamees (2015). Field Survey of Overheating Problems in Estonian Apartment Buildings, Architectural Science Research, vol. 58, no.1. pp

NABERS (2012) 'National Australian Built Environment Rating System', http://www.nabers.com.au/

Passive House Institute (PHI) (2012) http://www.passiv.de/en/index.html

Pyzdek T. (2003). Quality Engineering Handbook, 2nd Edition, ISBN 0824746147

RIBA (2012) BIM Overlay to the Outline Plan of Work. http://www.ribabookshops.com/planof-work/

RIBA (2011) Green Overlay to the RIBA Outline Plan of Work. RIBA Publishing, 15 Bonhill Street, London. ISBN 9781859464410

Scottish Government (2011) Technical Handbooks Section 7 - Sustainability. http://www.scotland.gov.uk/Topics/Built-Environment/Building/Buildingstandards/publications/pubtech/

Succar B, (2009). Building information modelling framework: A research and delivery foundation for industry stakeholders. Automation in Construction, Volume 18, Issue 3, p. 357-375.

Tuohy P G and Murphy G (2015) Are Current Design Processes and Policy Delivering Comfortable Low Carbon Buildings? ASR58.1

Tuohy, Paul Gerard (2009a) 'Simulation and BIM in building design, commissioning and operation: a comparison with the microelectronics industry'. In: Building Simulation 2009, 11th International Building Performance Simulation Association Conference, 2009-07-27 2009-07-30, Glasgow, UK.

Tuohy P G (2013) Strategies for low carbon buildings: Assessment of design options and translation of design intent into performance in practice. PhD Thesis, University of Strathclyde, 2013. https://pure.strath.ac.uk

USGBC (2012) LEED. http://www.usgbc.org/DisplayPage.aspx?CategoryID=19

Usable Buildings Trust (UBT) (2012) http://www.usablebuildings.co.uk/

Way, M. and Bordass, B., 2005. Making feedback and post-occupancy evaluation routine 2: Soft Landings: involving design and building teams in improving performance, Building Research \& Information 33(4), 353-360. 
Architectural Science Review, vol 58, 2015 